Riga, Latvia, November 15, 2019

\title{
CERTAIN ASPECTS OF THE INTERNATIONAL LEGAL OBLIGATIONS OF UKRAINE ON THE BAR'S ORGANIZATION AND ACTIVITY
}

\author{
Ruslan Skrynkovskyy ${ }^{1}$ \\ Olha Zaiats $^{2}$
}

DOI: https://doi.org/10.30525/978-9934-588-13-6-23

When joining the Council of Europe, Ukraine has undertaken international legal obligations to ensury the proper protection of the status of the legal profession (lawyers) and to establish a professional bar association on an independent basis at the legislative level (see paragraph ix of the article 11 of the Opinion No. 190 (1995) of the Parliamentary Assembly of the Council Of Europe on the joining of Ukraine to the Council of Europe dated September 26, 1995 [1]; paragraph 10 of Resolution of the Parliamentary Assembly of the Council of Europe 1346 (2003) «Honouring of Obligations and Commitments of Ukraine» dated September 29, 2003 [2] paragraph 7.3.6 of the Article 7.3 of Resolution of the Parliamentary Assembly of the Council of Europe 1755 (2010) «The Functioning of Democratic Institutions in Ukraine» dated November 04,2010 [3]).

In this context, in view of the current situation, the Ukrainian Bar (Art. 2 of the Law of Ukraine «On the Bar and Practice of Law» dated July 05, 2012 No. 5076-VI [4]) was defined at the legislative level as a nongovernmental self-governing institute providing protection, representation in court and other types of professional juridicial (legal) assistance (on an independent basis), as well as independently resolving all key issues of its organization and activity $[4 ; 5]$.

All attorneys of Ukraine, regardless of their will, were united in the Nongovernmental Non-commercial Professional Organization «Ukrainian National Bar Association» (UNBA), which, according to the Law of Ukraine «On the Bar and Practice of Law» (dated July 05, 2012 No. 5076-VI) [4], was created with the purpose of ensuring the implementation of the tasks of advocate self-government, enhancing the level of juridicial (legal) assistance provided by attorneys, the role and authority of the bar in society [6;7]. The historical background is presented in Table 1.

\footnotetext{
${ }^{1}$ Lviv University of Business and Law, Ukraine ORCID: http://orcid.org/0000-0002-2180-8055

2 Lviv State University of Internal Affairs, Ukraine ORCID: http://orcid.org/0000-0003-2872-5567
} 
Historical background [7, p. 11-12]

\begin{tabular}{|c|c|c|}
\hline DATE & EVENT & SIGNIFICANCE \\
\hline $\begin{array}{l}\text { September } \\
26,1995\end{array}$ & $\begin{array}{l}\text { Joining of Ukraine to the Council } \\
\text { of Europe }\end{array}$ & $\begin{array}{l}\text { 1. Ukraine assumes } \\
\text { obligations on ensuring the } \\
\text { proper protection of the legal } \\
\text { profession status and } \\
\text { establishing a professional bar } \\
\text { at the legislative level }\end{array}$ \\
\hline June 28,1996 & $\begin{array}{l}\text { Adoption of the Constitution of } \\
\text { Ukraine [8] }\end{array}$ & $\begin{array}{l}\text { 2. The Bar in Ukraine acts to } \\
\text { secure the right to defense } \\
\text { against prosecution and to } \\
\text { provide legal assistance in } \\
\text { courts and other state bodies } \\
\text { (Part } 2 \text { of Art. } 59 \text { of the } \\
\text { Constitution of Ukraine) }\end{array}$ \\
\hline July 05, 2012 & $\begin{array}{l}\text { Adoption of the Law of Ukraine } \\
\text { «On the Bar and Practice of } \\
\text { Law» }[4]\end{array}$ & \multirow{2}{*}{$\begin{array}{l}\text { 3. The Bar in Ukraine is } \\
\text { constituted as a non- } \\
\text { governmental self-governing } \\
\text { institute }\end{array}$} \\
\hline $\begin{array}{l}\text { August } 15 \text {, } \\
2012\end{array}$ & $\begin{array}{l}\text { Coming into force of the Law of } \\
\text { Ukraine «On the Bar and } \\
\text { Practice of Law» [4] }\end{array}$ & \\
\hline $\begin{array}{l}\text { November } \\
20,2012\end{array}$ & $\begin{array}{l}\text { Coming into force of the new } \\
\text { Criminal Procedure Code of } \\
\text { Ukraine [9] }\end{array}$ & $\begin{array}{l}\text { 4. Only attorneys can be } \\
\text { defenders in criminal } \\
\text { investigations }\end{array}$ \\
\hline $\begin{array}{l}\text { November } \\
19,2012\end{array}$ & $\begin{array}{l}\text { Registration of the «Ukrainian } \\
\text { National Bar Association» } \\
\text { (UNBA) [6] } \\
\text { (https://unba.org.ua/) }\end{array}$ & $\begin{array}{l}\text { 5. The non-commercial } \\
\text { Professional Organization } \\
\text { «Ukrainian National Bar } \\
\text { Association» (UNBA), which } \\
\text { consolidates all the attorneys } \\
\text { if Ukraine, started to operate }\end{array}$ \\
\hline $\begin{array}{l}\text { June } 02 \text {, } \\
2016\end{array}$ & $\begin{array}{l}\text { Introduction of amendments to } \\
\text { the Constitution of Ukraine (on } \\
\text { justice) [10] }\end{array}$ & \multirow{2}{*}{$\begin{array}{l}\text { 6. The attorney's monopoly } \\
\text { on the standing in the law } \\
\text { proceedings of Ukraine }\end{array}$} \\
\hline $\begin{array}{l}\text { September } \\
30,2016\end{array}$ & $\begin{array}{l}\text { Coming into force of the } \\
\text { amendments to the Constitution } \\
\text { of Ukraine (on justice) }[8 ; 10]\end{array}$ & \\
\hline $\begin{array}{l}\text { December } \\
15,2017\end{array}$ & $\begin{array}{l}\text { Coming into force the } \\
\text { amendments to the Commercial } \\
\text { and Procedural Code of Ukraine, } \\
\text { the Civil Procedural Code of } \\
\text { Ukraine, the Code of } \\
\text { Administrative Proceedings of } \\
\text { Ukraine and other legislative acts } \\
\text { [11] }\end{array}$ & $\begin{array}{l}\text { 7. The attorneys only can } \\
\text { stand for the other persons in } \\
\text { court, except the events, } \\
\text { regulated by the court }\end{array}$ \\
\hline
\end{tabular}


Thus, with the adoption and coming into force of the Law of Ukraine «On the Bar and Practice of Law» (dated July 5, 2012, No. 5076-VI) [4], which needs improvement, the registration of the National Bar Association of Ukraine and the beginning of its activity [6], Ukraine formally fulfilled its international legal obligations to the Council of Europe to ensure the protection of the status of the legal profession (lawyers) and the establishment of a professional bar association at the legislative level [7]. At the same time, it is also worth noting that today the professional bar community emphasizes the problems of violation of the lawyers' rights and the guarantees of advocacy in Ukraine (when providing professional juridicial (legal) assistance to a client on an independent basis). Independent bar is a necessary and important prerequisite for securing the rule of law and democracy in society $[7 ; 12]$.

\section{References:}

1. Vysnovok № 190 (1995). Parlamentskoi Asamblei Rady Yevropy shchodo vstupu Ukrainy do Rady Yevropy vid 26.09.1995 r. Retrieved September 10, 2019, from https://zakon.rada.gov.ua/laws/show/994_590/conv (in Ukrainian)

2. Rezoliutsiia 1346 (2003). Parlamentskoi Asamblei Rady Yevropy «Vykonannia Ukrainoiu svoikh oboviazkiv ta zoboviazan» vid 29.09.2003 r. Retrieved September 10, 2019, from https://zakon.rada.gov.ua/laws/show/994_608 (in Ukrainian)

3. Rezoliutsiia 1755 (2010). Parlamentskoi Asamblei Rady Yevropy «Funktsionuvannia demokratychnykh instytutsii v Ukraini» vid 04.10.2010 r. Retrieved September 10, 2019, from https://zakon.rada.gov.ua/laws/show/994_a19 (in Ukrainian)

4. Pro advokaturu ta advokatsku diialnist [On the Bar and Legal Practice]: Zakon Ukrainy vid 05.07.2012 r. № 5076-VI (iz zminamy ta dopovnenniamy). Retrieved September 10, 2019, from http://zakon5.rada.gov.ua/laws/show/5076-17 (in Ukrainian)

5. Antoniuk, S. (2019). Lawyer as a Subject of Providing Legal Assistance to a Client on a Professional, Independent basis. Path of Science. Vol. 5, No 5. P. 4001-4016. doi: http://dx.doi.org/10.22178/pos.46-6

6. Statut Nederzhavnoi nekomertsiinoi profesiinoi orhanizatsii «Natsionalna asotsiatsiia advokativ Ukrainy» [Charter of the Ukrainian National Bar Association]: Zatverdzheno rishenniam Ustanovchoho zizdu advokativ Ukrainy vid 17.11.2012 r. Retrieved September 10, 2019, from https://unba.org.ua/assets/uploads/legislations/ inshi-dokumenty/statut_naau.pdf(in Ukrainian)

7. Tinovyi zvit «ÂAdvokatura Ukrainy: uroky pershykh rokiv samovriadnosti». Kyiv: HO «Laboratoriia zakonodavchykh initsiatyv». 2018. 86 s. (in Ukrainian)

8. Konstytutsiia Ukrainy [The Constitution of Ukraine]. Zakon Ukrainy No. 254к/96-BP, 28 June 1996. Retrieved September 10, 2019, from http://zakon.rada.gov.ua/laws/show/254к/96-вp (in Ukrainian)

9. Kryminalnyi protsesualnyi kodeks Ukrainy [The Criminal Procedural Code of Ukraine] vid 13.04.2012 r. № 4651-VI. Retrieved September 10, 2019, from https://zakon.rada.gov.ua/laws/show/4651-17 (in Ukrainian) 
10. Pro vnesennia zmin do Konstytutsii Ukrainy (shchodo pravosuddia) [On Amendments to the Constitution of Ukraine (on Justice)]: Zakon Ukrainy vid 02.06 .2016 r. № 1401-VIII. Retrieved September 10, 2019, from https://zakon.rada.gov.ua/laws/show/1401-19 (in Ukrainian)

11. Pro vnesennia zmin do Hospodarskoho protsesualnoho kodeksu Ukrainy, Tsyvilnoho protsesualnoho kodeksu Ukrainy, Kodeksu administratyvnoho sudochynstva Ukrainy ta inshykh zakonodavchykh aktiv: Zakon Ukrainy vid 03.10.2017 r. № 2147-VIII. Retrieved September 10, 2019, from https://zakon.rada.gov.ua/laws/show/2147-19 (in Ukrainian)

12. Zvit pro porushennia prav advokativ ta harantii advokatskoi diialnosti $\mathrm{v}$ Ukraini za 2013-2018 rr. [Report on violation of the rights of lawyers and guarantees of advocacy in Ukraine for 2013-2018]. Kyiv: Natsionalna asotsiatsiia advokativ Ukrainy. 2018. 44 s. (in Ukrainian) 